\title{
Ontogenetic niche changes in haddock Melanogrammus aeglefinus reflected by stable isotope signatures, $\delta^{13} \mathrm{C}$ and $\delta^{15} \mathrm{~N}$
}

\author{
Silje Ramsvatn*, Torstein Pedersen \\ Department of Arctic and Marine Biology, University of Tromsø, 9037 Tromsø, Norway
}

\begin{abstract}
We investigated stable nitrogen $\left(\delta^{15} \mathrm{~N}\right)$ and carbon $\left(\delta^{13} \mathrm{C}\right)$ isotope signatures in haddock Melanogrammus aeglefinus in Ullsfjord, Norway, and found evidence of an ontogenetic shift as a result of growth but in the absence of other morphological changes. Stable isotope signatures and trophic level (TL) changed significantly from a pelagic signature and a low TL to a more benthic associated signature and higher TL when the fish were ca. $20 \mathrm{~cm}$ in length. The stable isotope signatures of haddock were compared with those of Atlantic cod Gadus morhua from the same system, other main demersal fish species in the fjord, and haddock from the adjacent fjord, Sørfjord. Our results indicate that both haddock and cod are opportunistic feeders, feeding on the abundant crustaceans in the fjords. Several of the large demersal fish species in Ullsfjord had very similar stable isotope signatures, which reflected their predation on similar prey types.
\end{abstract}

KEY WORDS: Diet · Demersal fish · Gadoids · Feeding ecology · Trophic level · Young-of-the-year Resale or republication not permitted without written consent of the publisher

\section{INTRODUCTION}

Our understanding of life history traits as well as interactions of prey and predatory species is important for fisheries management. As we move towards improving fisheries management through ecosystem-based management, knowledge of size-based feeding changes is essential for understanding food webs. High latitude ecosystems are relatively low in diversity and a few top predators are thought to drive the ecosystem through top-down control (Frank et al. 2007). Haddock Melanogrammus aeglefinus is one of the major commercial species in the North Sea, Barents Sea and off the coast of Norway. Recent years the spawning stock biomass (SSB) of northeast Arctic haddock in the Barents Sea and off the coast of northern Norway has been increasing, and for 2012 it is expected to be at a record high of $413000 \mathrm{t}$ (ICES 2011). While the oceanic offshore northeast Arctic stock of Atlantic cod Gadus morhua is historically large, the SSB and recruitment (age 3) of the coastal cod stock inhabiting coastal and fjord areas is at a historical low (ICES 2011). Cod and haddock are therefore important in this region both as predators with top-down effects as well as for direct exploitation.

Ullsfjord is a high latitude fjord ecosystem at $70^{\circ} \mathrm{N}$ in northern Norway. The fjord supports small-scale local fisheries common in fjords along the Norwegian coast. The main target species are Atlantic cod, deep-water shrimp Pandalus borealis, haddock and saithe Pollachius virens, but less exploited demersal fish species also inhabit the Ullsfjord ecosystem, including long rough dab Hippoglossoides platessoides, whiting Merlangius merlangus and witch flounder Glyptocephalus cynoglossus (Nøstvik \& Pedersen 1999). Young-of-the-year (YOY) haddock in the size range of 10 to $20 \mathrm{~cm}$ have high biomasses in Ullsfjord and are assumed to be important prey for large predatory fish and seabirds (Bugge et al. 2011). 
Both haddock and cod have small eggs and pelagic larvae and therefore change from a pelagic niche to a more demersally associated niche in larger fish as they grow (Bergstad et al. 1987). Haddock settle in the demersal habitat when they are between 4 and $14 \mathrm{~cm}$, and cod settle at 4 to $8 \mathrm{~cm}$ (Robb \& Hislop 1980, Godø et al. 1989). At this stage the diet of haddock is reported to change from pelagic copepods to demersal prey such as mussels, polychaetes and small fish as they settle in deep waters, while coastal cod continue to eat pelagic prey like copepods and settle in inshore waters (Demain et al. 2011). By changing their habitat or diet through life young individuals can maximize their fitness by reducing intraspecific competition and predation from other predatory fish as well as from larger conspecifics (Werner \& Gilliam 1984). Several studies have suggested that inter- and intraspecific competition may be a driver of resource use and niche diversification (e.g. Svanbäck \& Bolnick 2007, Shaw et al. 2008).

Stable isotopes in tissues of marine organisms reflect the diet of consumers and their analysis is becoming a widely accepted and applied tool for determining food web structure and carbon flow in ecosystem ecology (e.g. Fry 1988, Hobson et al. 2002, Nilsen et al. 2008). The nitrogen isotope ratio $\left(\delta^{15} \mathrm{~N}\right)$ is used as an indication of the trophic level (TL) of the animal (Cabana \& Rasmussen 1996) because tissue $\delta^{15} \mathrm{~N}$ values increase up the food chain. A mean fractionation factor of $3.4 \%$ per trophic level has been estimated (Minagawa \& Wada 1984, Post 2002). The carbon isotope ratio $\left(\delta^{13} \mathrm{C}\right)$ is used to determine whether the food source is linked to the pelagic or benthic zone (Peterson \& Fry 1987, Hobson \& Welch 1992, Post 2002). Carbon originating from pelagic phytoplankton has a low (highly negative) $\delta^{13} \mathrm{C}$, while the benthic and littoral zones are more enriched in ${ }^{13} \mathrm{C}$ (less negative $\delta^{13} \mathrm{C}$ ). Because the trophic fractionation of $\delta^{13} \mathrm{C}$ is small ( 0 to $1 \%$ per TL) (Hobson \& Welch 1992, Post 2002) this can be used to separate primary sources of carbon. The isotopic niche refers to the area of a $\delta^{13} \mathrm{C}-\delta^{15} \mathrm{~N}$ bi-plot occupied by one species (Newsome et al. 2007).

Most work on early life feeding of gadoids has been based on traditional stomach sampling (e.g. Pedersen \& Fossheim 2008, Dalpadado et al. 2009); this is a time-consuming method that only provides a 'snapshot' of what has been recently consumed. In this study we present data from recently collected samples of the predatory fishes from Ullsfjord, with a main focus on haddock. Our objectives were to investigate whether stable isotope signatures (1) of haddock and cod varied with size within species,
(2) differed between haddock and cod, (3) differed between other demersal species in Ullsfjord and (4) differed between haddock with different geographic distributions.

\section{MATERIALS AND METHODS}

\section{Sampling and stable isotope analysis}

Sampling was done from RV 'Johan Ruud' (University of Tromsø) at 5 locations in Ullsfjord within $1 \mathrm{wk}$ in February 2010. Demersal fish species were collected by bottom trawl with a Campelen shrimp trawl that had a circumference of 1300 meshes, equipped with rockhopper gear and a $20 \mathrm{~mm}$ inner net mounted in the cod-end. Trawling duration was 20 min and average speed was 2 knots $\left(3.7 \mathrm{~km} \mathrm{~h}^{-1}\right)$. Pelagic-feeding copepods, Calanus finmarchicus, were collected by a WP2 plankton net $(180 \mu \mathrm{m}$ mesh) at the same stations and the haul was pulled through the whole water column. C. finmarchicus were collected to use as a baseline for the pelagic food web. The depth of the stations varied from 120 to $425 \mathrm{~m}$ (Fig. 1). Individual biometric measurements such as length, weight and sex were recorded for the fish samples. Muscle samples of about 1 to $2 \mathrm{~cm}^{3}$ were taken from the area between the head and first dorsal fin, above the lateral line of each fish. For C. finmarchicus, whole animals were used for analysis. All samples were frozen at $-18^{\circ} \mathrm{C}$ until further analysis. In the laboratory the skin was removed from the fish muscle, and the samples were rinsed in distilled water before they were dried at $60^{\circ} \mathrm{C}$ for $48 \mathrm{~h}$, subsequently ground into a fine powder with a mortar and pestle and stored in microcentrifuge tubes at $-18^{\circ} \mathrm{C}$ until further analysis. C. finmarchicus samples were treated with $2 \mathrm{~N}$ $\mathrm{HCl}$ before spectrometry analysis to remove nondietary carbon in the exoskeleton. The mass spectrometry analysis for determination of $\delta^{15} \mathrm{~N}$ and $\delta^{13} \mathrm{C}$ was conducted at the Institute for Energy Technology (IFE), Kjeller, Norway, with a Nu Horizon isotope ratio mass spectrometer ( $\mathrm{Nu}$ Instruments). Stable isotope ratios are expressed in $\delta$ notation as deviation in parts per thousand (\%) from a standard material, Pee Dee belemnite limestone for $\delta^{13} \mathrm{C}$ and atmospheric nitrogen for $\delta^{15} \mathrm{~N}$.

Because lipids are depleted in ${ }^{13} \mathrm{C}$ relative to ${ }^{12} \mathrm{C}$, the carbon isotope values $\left(\delta^{13} \mathrm{C}\right)$ of lipid-rich animals such as copepods will be strongly negative. As lipid removal was not done chemically we used regression Eq. (1) (Post et al. 2007) to normalize for the effect of 


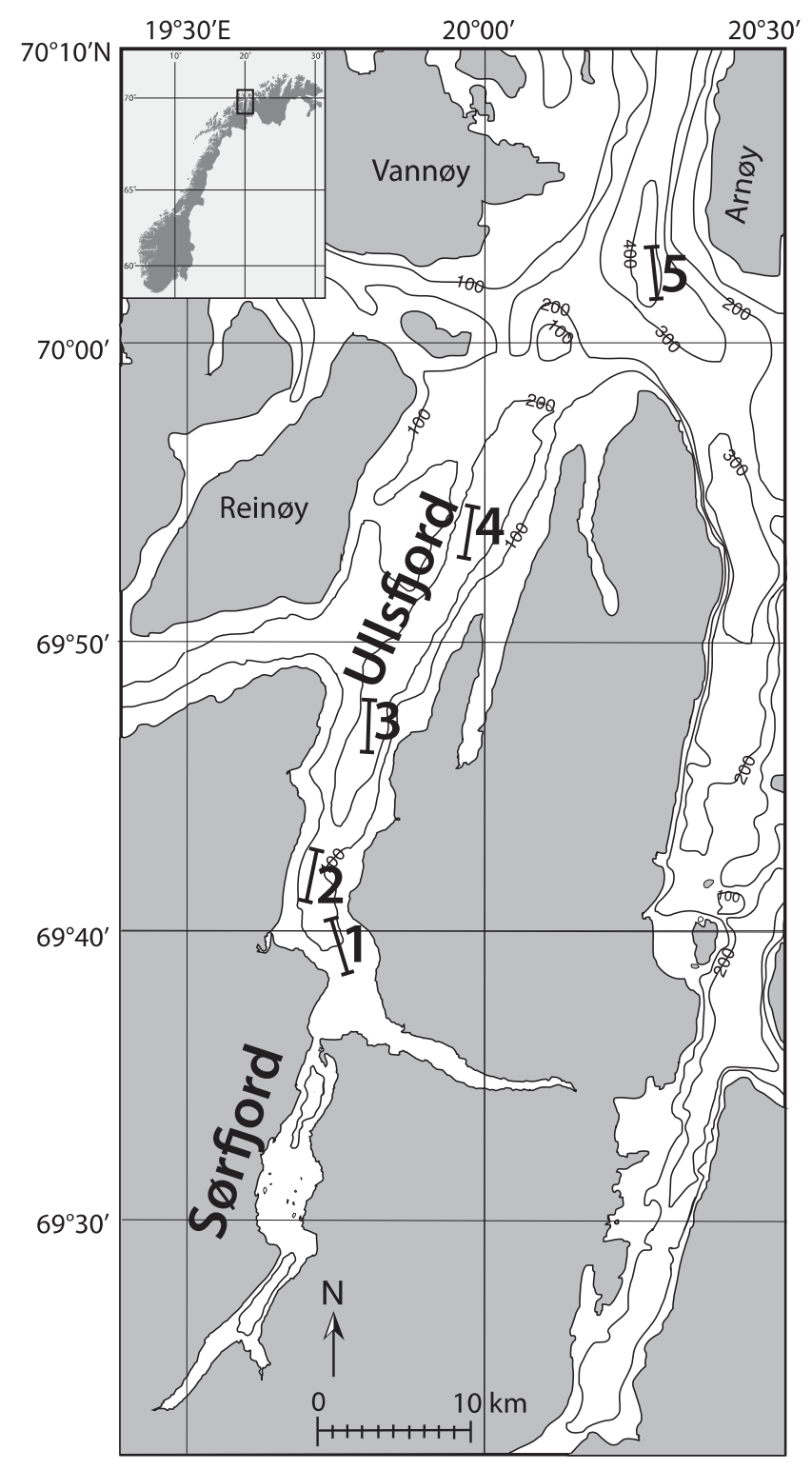

Fig. 1. Sampling area in Ullsfjord, northern Norway. The trawling grounds are marked as bars. Average depths are

(1) $125 \mathrm{~m}$, (2) $120 \mathrm{~m}$, (3) $270 \mathrm{~m}$, (4) $275 \mathrm{~m}$ and (5) $425 \mathrm{~m}$

lipids, and Eq. (2) (Abrantes et al. 2012) to calculate the amount of lipids in the samples.

$$
\begin{aligned}
& \delta^{13} \mathrm{C}_{\text {normalized }}=\delta^{13} \mathrm{C}_{\text {untreated }}-3.32+0.99 \times \mathrm{C}: \mathrm{N} \\
& \text { Lipids (\%) }=-16.53+6.27 \times \mathrm{C}: \mathrm{N}
\end{aligned}
$$

Haddock had an average $\mathrm{C}: \mathrm{N}$ ratio of 3.16 (SD, 0.06). This is equivalent to a lipid level of $3.29 \%$ according to Eq. (2). For marine animals with a lipid level $<5 \%$ it is not necessary to remove or convert the $\delta^{13} \mathrm{C}$ values to account for lipids (Abrantes et al. 2012). The C:N ratio was weakly correlated with fish length (Spearman's rank correlation: $\mathrm{r}_{\mathrm{S}}=0.38, \mathrm{p}<$ 0.001). However, for comparative reasons with other studies, and because 2 witch flounders had a C:N ratio above 5 we chose to convert all values. This was done so treatment would be the same for all values when comparing them statistically.

TL was calculated from the following equation:

$$
\mathrm{TL}=\left(\delta^{15} \mathrm{~N}_{\text {consumer }}-\delta^{15} \mathrm{~N}_{\text {base }}\right) / \Delta \delta^{15} \mathrm{~N}+\mathrm{TL} \text { base }
$$

where $\delta^{15} \mathrm{~N}_{\text {consumer }}$ is the $\delta^{15} \mathrm{~N}$ of the group or species in question, and $\delta^{15} \mathrm{~N}_{\text {base }}$ and TL base are the $\delta^{15} \mathrm{~N}$ and TL values of the baseline species, respectively. We selected the herbivorous copepod Calanus finmarchicus and assumed it had a TL of 2.0 (Petursdottir et al. 2008). $\Delta \delta^{15} \mathrm{~N}$ is the trophic enrichment factor per TL, and we chose to use $3.4 \%$ as this has been suggested as an average enrichment factor (Minagawa \& Wada 1984, Post 2002).

\section{Statistics}

All the figures and statistical analyses were made by using the R software (http://cran.r-project.org/). Because the data did not show homogeneity of variance when tested with a Brown-Forsythe Levenetype test (BF Levene), non-parametric tests were chosen to test for differences between length groups and between species. Two groups such as haddock and cod were tested by using the Wilcoxon rank sum test with continuity correction $\left(\mathrm{WR}_{\mathrm{c}}\right)$. When testing whether stable isotope values differed between length groups within one species, the nonparametric Kruskal-Wallis rank sum test (KW) was chosen. A pairwise comparison using the Wilcox rank sum test with Bonferroni correction $\left(\mathrm{WR}_{\mathrm{B}}\right)$ was used as a post hoc test to investigate which length groups were significantly different. For correlation tests we used Spearman's rank correlation $\left(\mathrm{r}_{\mathrm{S}}\right)$. Frequency plots were used to show the distribution of the isotope signatures within one species and the overlap between species. The area under the curve is standardized to 1 .

\section{RESULTS}

Haddock displayed large variances in stable isotope values but had low $\delta^{15} \mathrm{~N}$ and $\delta^{13} \mathrm{C}$ signatures at small fish lengths $(20 \mathrm{~cm}$ and smaller), and a more enriched signature of $\delta^{13} \mathrm{C}$ and $\delta^{15} \mathrm{~N}$ at larger sizes (Fig. 2a,b, Table 1). When we divided the haddock into length groups, the smallest group (10 to $20 \mathrm{~cm}$ ) 


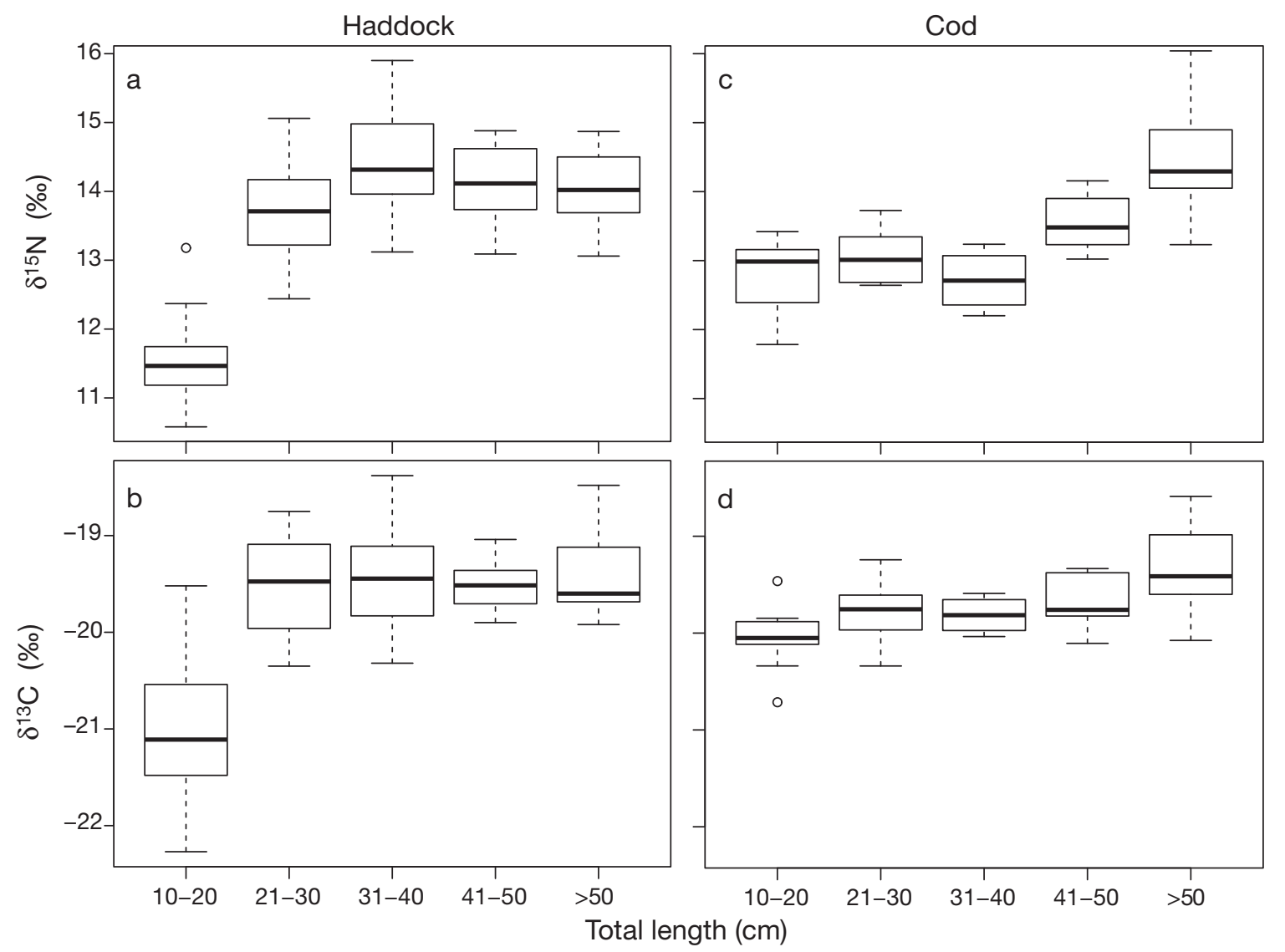

Fig. 2. Melanogrammus aeglefinus and Gadus morhua. Comparison of isotope signatures of the different length groups of haddock and cod: (a) $\delta^{15} \mathrm{~N}$ haddock, (b) $\delta^{13} \mathrm{C}$ haddock, (c) $\delta^{15} \mathrm{~N}$ cod and (d) $\delta^{13} \mathrm{C}$ cod. Box plot shows median (solid thick line), 25th and 75th quantiles (box) and minimum and maximum values excluding outliers (whiskers). Circles indicate possible outliers. See Table 1 for sample sizes (n)

Table 1. Mean length per length group (for haddock and cod), mean $( \pm \mathrm{SD})$ stable isotope signatures $\delta^{15} \mathrm{~N}$ and $\delta^{13} \mathrm{C}, \mathrm{C}: \mathrm{N}$ ratio and trophic level (TL) for haddock Melanogrammus aeglefinus, cod Gadus morhua and main demersal species in Ullsfjord, Norway. $\delta^{13} \mathrm{C}$ values are lipid-corrected using Eq. (1) and TL was calculated according to Eq. (3). n: number of observations

\begin{tabular}{|c|c|c|c|c|c|c|c|}
\hline Species & $\begin{array}{l}\text { Length group } \\
\text { (range, } \mathrm{cm} \text { ) }\end{array}$ & $\begin{array}{l}\text { Mean length } \\
\text { (cm) }\end{array}$ & $\begin{array}{c}\text { Mean } \delta^{15} N \\
( \pm \mathrm{SD})\end{array}$ & $\begin{array}{c}\text { Mean } \delta^{13} \mathrm{C} \\
( \pm \mathrm{SD})\end{array}$ & $\mathrm{C}: \mathrm{N}$ ratio & TL & $\mathrm{n}$ \\
\hline \multirow[t]{6}{*}{ Melanogrammus aeglefinus } & $16-75$ & 28.83 & $12.96( \pm 1.42)$ & $-20.13( \pm 0.96)$ & 3.16 & 3.16 & 75 \\
\hline & $10-20$ & 17.97 & $11.51( \pm 0.53)$ & $-21.03( \pm 0.65)$ & 3.13 & 2.73 & 32 \\
\hline & $21-30$ & 25.78 & $13.78( \pm 0.72)$ & $-19.50( \pm 0.53)$ & 3.19 & 3.40 & 18 \\
\hline & $31-40$ & 35.00 & $14.45( \pm 0.81)$ & $-19.43( \pm 0.57)$ & 3.17 & 3.60 & 10 \\
\hline & $41-50$ & 45.88 & $14.11( \pm 0.61)$ & $-19.51( \pm 0.27)$ & 3.17 & 3.50 & 8 \\
\hline & $>50$ & 58.00 & $14.04( \pm 0.66)$ & $-19.37( \pm 0.50)$ & 3.18 & 3.48 & 7 \\
\hline \multirow[t]{6}{*}{ Gadus morhua } & $10-106$ & 45.39 & $13.67( \pm 0.92)$ & $-19.61( \pm 0.44)$ & 3.18 & 3.37 & 58 \\
\hline & $10-20$ & 13.50 & $12.94( \pm 0.61)$ & $-20.06( \pm 0.32)$ & 3.27 & 3.10 & 10 \\
\hline & $21-30$ & 25.90 & $13.11( \pm 0.44)$ & $-19.77( \pm 0.33)$ & 3.18 & 3.20 & 11 \\
\hline & $31-40$ & 34.25 & $13.42( \pm 1.03)$ & $-19.81( \pm 0.20)$ & 3.15 & 3.09 & 4 \\
\hline & $41-50$ & 44.43 & $13.69( \pm 0.55)$ & $-19.66( \pm 0.30)$ & 3.15 & 3.33 & 7 \\
\hline & $>50$ & 68.08 & $14.34( \pm 0.67)$ & $-19.33( \pm 0.40)$ & 3.15 & 3.60 & 26 \\
\hline Hippoglossoides platessoides & $25-34$ & 29.00 & $14.01( \pm 0.59)$ & $-19.01( \pm 0.28)$ & 3.09 & 3.47 & 5 \\
\hline Merlangius merlangus & $24-34$ & 28.58 & $14.14( \pm 0.35)$ & $-19.45( \pm 0.21)$ & 3.09 & 3.50 & 19 \\
\hline Glyptocephalus cynoglossus & $25-46$ & 38.63 & $14.05( \pm 0.42)$ & $-18.38( \pm 0.43)$ & 3.28 & 3.48 & 27 \\
\hline Calanus finmarchicus & & & $9.03( \pm 0.13)$ & $-19.90( \pm 0.57)$ & 7.29 & 2.0 & 15 \\
\hline
\end{tabular}


was significantly different from all the other length groups (KW, WR $R_{B}: p<0.01$ for $\delta^{15} \mathrm{~N}$ and $\delta^{13} \mathrm{C}$ ). Mean $\delta^{13} \mathrm{C}$ for the smallest group (10 to $20 \mathrm{~cm}$ ) of haddock was $-21.03 \%$, while the mean for the second smallest group ( 21 to $30 \mathrm{~cm}$ ) was $-19.50 \%$. The mean $\delta^{15} \mathrm{~N}$ of the smallest group was $11.51 \%$ and the second group had a mean of $13.78 \%$. The $\delta^{15} \mathrm{~N}$ and $\delta^{13} \mathrm{C}$ values were highly correlated $\left(r_{S}=0.90\right)$. The smallest group of haddock was distinct from the larger ones in the isotope bi-plot (Fig. 3). The distribution for $\delta^{15} \mathrm{~N}$ values was bimodal with modes of about $11.5 \%$ and $14 \%$, respectively (Fig. 3).

Cod had no marked shift in stable isotopes with increasing length (Fig. 2c,d). $\delta^{15} \mathrm{~N}$ and $\delta^{13} \mathrm{C}$ signatures for cod in the 10 to $20 \mathrm{~cm}$ size group were significantly different from cod $>40 \mathrm{~cm}\left(\mathrm{KW}, \mathrm{WR}_{\mathrm{B}}: \mathrm{p}<\right.$ 0.01 ) but not from those between 21 and $40 \mathrm{~cm}$. For cod and haddock of 10 to $20 \mathrm{~cm}$ length both isotopes differed between species (Fig. 4). The small haddock $(10$ to $20 \mathrm{~cm})$ were depleted in both ${ }^{15} \mathrm{~N}\left(\mathrm{WR}_{\mathrm{c}}\right.$ : $\mathrm{p}<$ $0.001)$ and ${ }^{13} \mathrm{C}\left(\mathrm{WR}_{\mathrm{c}}: \mathrm{p}<0.001\right)$ compared with those of cod. For larger cod and haddock the stable isotopes signatures were very similar (Fig. 5).

In addition to cod and haddock, we investigated several other demersal fish species in Ullsfjord. For comparisons between species we used individuals in
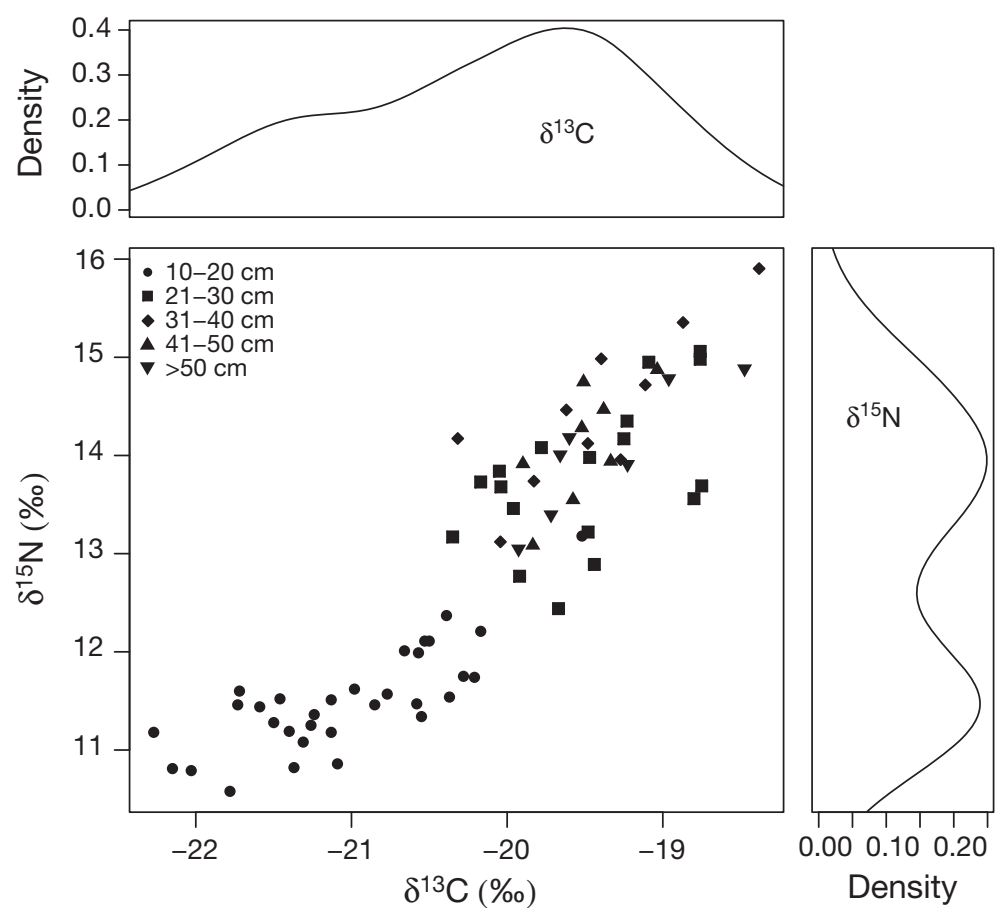

Fig. 3. Melanogrammus aeglefinus. Scatterplot showing haddock $\delta^{13} \mathrm{C}$ and $\delta^{15} \mathrm{~N}$ values $(\mathrm{n}=75)$. The distribution of the values along the axes are shown in frequency plots. $\delta^{13} \mathrm{C}$ is shown above the scatterplot and $\delta^{15} \mathrm{~N}$ is on the right

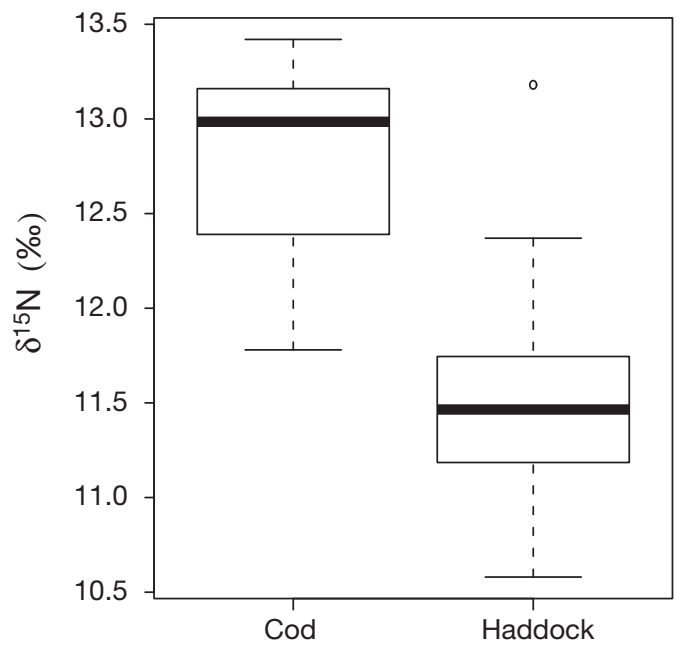

Fig. 4. Gadus morhua and Melanogrammus aeglefinus. Comparison of $\delta^{15} \mathrm{~N}$ for cod $(\mathrm{n}=10)$ and haddock $(\mathrm{n}=32)$ for fish lengths of $20 \mathrm{~cm}$ and smaller. See Fig. 2 for description of box plots

the size range of 25 to $45 \mathrm{~cm}$ from haddock and cod to match the size range for which we had samples from whiting, long rough dab and witch flounder. The demersal species showed large overlaps in both $\delta^{13} \mathrm{C}$ and $\delta^{15} \mathrm{~N}$ signatures (Figs. $6 \&$ 7). Witch flounder had significantly higher $\delta^{13} \mathrm{C}$ than did the other demersal species we sampled, and $\delta^{13} \mathrm{C}$ in long rough dab was significantly higher than in $\operatorname{cod}\left(\mathrm{WR}_{\mathrm{B}}: \mathrm{p}<0.05\right)$. There was no significant difference in $\delta^{13} \mathrm{C}$ between cod and haddock, cod and whiting, haddock and long rough dab, haddock and whiting or whiting and long rough dab. However, for cod in the size range of 25 to $45 \mathrm{~cm} \delta^{15} \mathrm{~N}$ was significantly lower than in haddock, whiting and witch flounder $\left(\mathrm{WR}_{\mathrm{B}}: \mathrm{p}<0.05\right)$, while no statistical difference in $\delta^{15} \mathrm{~N}$ signatures was apparent in the other species.

After conversion (Eq. 1), the values of $\delta^{13} \mathrm{C}$ samples that had a $\mathrm{C}: \mathrm{N}$ ratio under 3.32 (low in lipids) became slightly more negative. For haddock the $\delta^{13} \mathrm{C}$ decreased on average by 0.19 (SD, 0.06 ; range, 0.06 to 0.32 ). For cod the $\delta^{13} \mathrm{C}$ decreased on average by 0.18 (SD, 0.07 ; range, 0.02 to $0.29)$. In contrast, for the lipid-rich copepod Calanus finmarchicus, which had an average C:N ratio of 7.3 , the values of $\delta^{13} \mathrm{C}$ increased by an average of 4.21 (SD, 0.91 ; range, 5.67 to 2.63 ).

Haddock was at the lowest overall average TL for the fish species at 3.16 and 


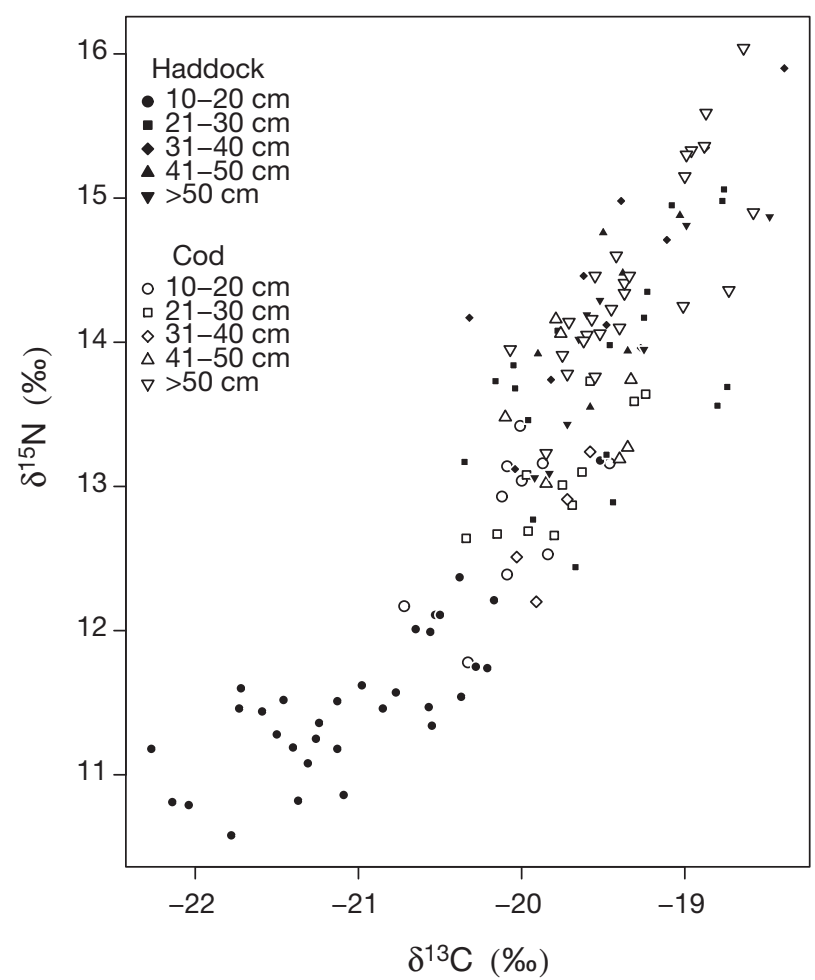

Fig. 5. Gadus morhua and Melanogrammus aeglefinus. Scatterplot of $\delta^{13} \mathrm{C}$ and $\delta^{15} \mathrm{~N}$ isotope signatures for $\operatorname{cod}(\mathrm{n}=$ 58) (open symbols) and haddock $(n=75)$ (solid symbols)

whiting was at the highest at TL 3.50 (Table 1). The smallest group of haddock was at TL 2.73, the lowest of all groups, while haddock in the length group of 31 to $40 \mathrm{~cm}$ was at TL 3.60 , the same as the largest group of $\operatorname{cod}(>50 \mathrm{~cm})$.

\section{DISCUSSION}

\section{Ontogenetic niche shift and size-dependent niche diversification}

We can interpret the change in $\delta^{13} \mathrm{C}$ in haddock between the 10 to $20 \mathrm{~cm}$ group and the 21 to $30 \mathrm{~cm}$ group to be a result of a change in diet from pelagic to more demersally associated prey. This ontogenetic change in isotopic values has to our knowledge not been described previously. An abrupt change in diet and habitat can correspond to the metamorphosis from larvae to juveniles in, for example, largemouth bass Micropterus salmonides (Post 2003), yellowfin tuna Thunnus albacares (Graham et al. 2007) and red snapper Lutjanus campechanus (Wells et al. 2008). However, abrupt changes in diet as a result of increased size, but otherwise no morphological

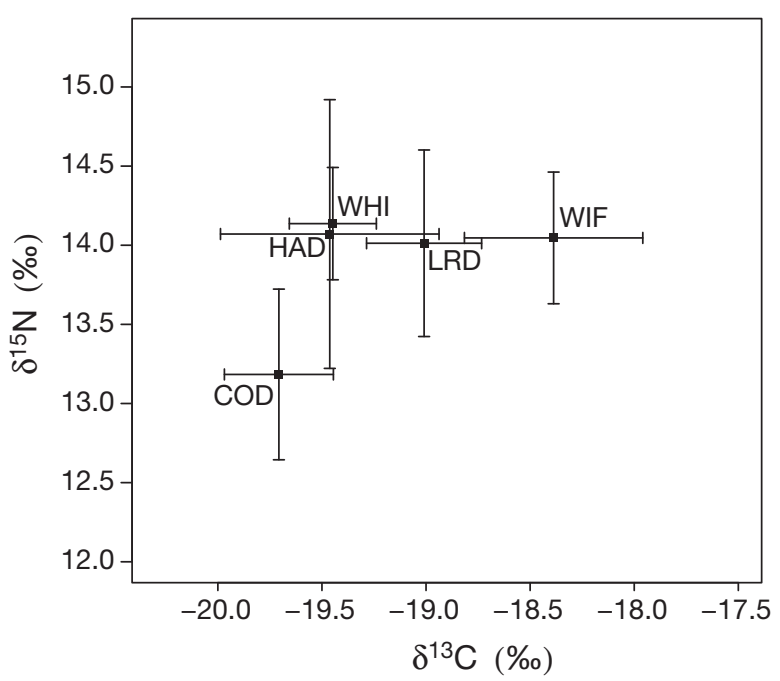

Fig. 6. Demersal fish species' stable isotope signatures $\left(\delta^{15} \mathrm{~N}\right.$ and $\delta^{13} \mathrm{C}$ ) displayed with means (solid squares) and error bars representing $\pm 1 \mathrm{SD}$. HAD: haddock Melanogrammus aeglefinus (25 to $45 \mathrm{~cm}$ ); COD: cod Gadus morhua (25 to $45 \mathrm{~cm}) ;$ WHI: whiting Merlangius merlangus; LRD: long rough dab Hippoglossoides platessoides; WIF: witch flounder Glyptocephalus cynoglossus

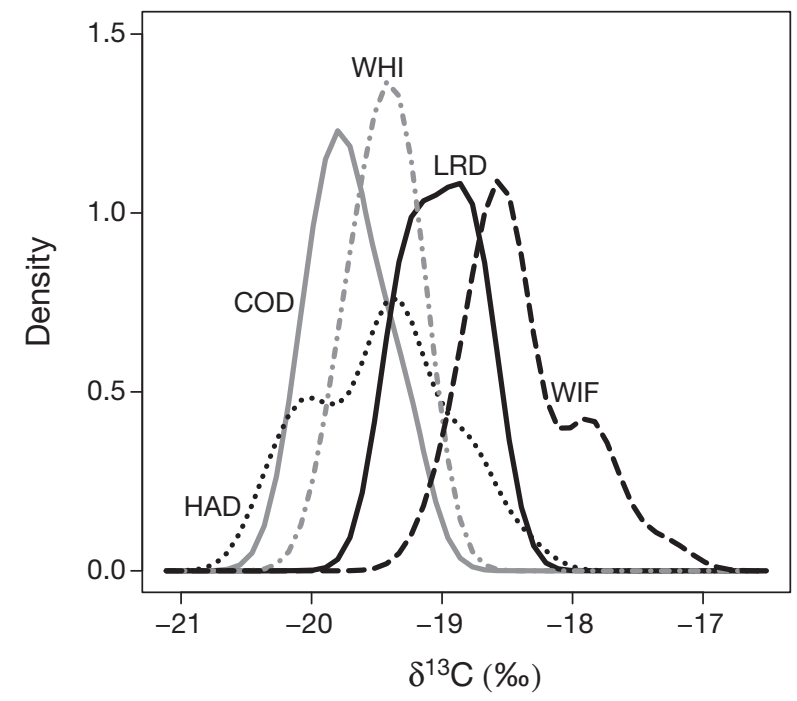

Fig. 7. Overlap in $\delta^{13} \mathrm{C}$ among demersal species in the Ullsfjord system plotted in a frequency plot. Species abbreviations as in Fig. 6

change, are not well described. Small haddock in Ullsfjord were more depleted in ${ }^{13} \mathrm{C}$ than were larger fish, which indicates they feed on prey more connected to the pelagic zone.

The turnover time of isotopes in the muscle will be shorter in younger and faster-growing individuals than in larger, slow-growing fish. YOY haddock will increase their body mass about 9 times as they grow; 
they settle at about $10 \mathrm{~cm}$ in size in August to October (Godø et al. 1989, Dalpadado et al. 2009) and grow to $20 \mathrm{~cm}$ at about $1 \mathrm{yr}$ of age the next spring. Weidel et al. (2011) found the half-life of $\delta^{13} \mathrm{C}$ in 0 -age-group freshwater species to be from 8 to $18 \mathrm{~d}$. Although the haddock in our survey were larger than the juveniles examined by Weidel et al. (2011), the growth of haddock and cod is so fast during the first year that the isotopes found in the muscle are a reflection of the diet within a relatively short time span. Also, if the observed signatures did originate from when the fish were in the pre-settlement stage, we would expect the same signature from the YOY cod, but this was not the case.

The difference in TL value for haddock was $0.75 \mathrm{TL}$ from the smallest to the largest length group. The 31 to $40 \mathrm{~cm}$ size group had a TL of 3.60 meaning it was 0.86 TL higher than the smallest group. The bimodal distribution of haddock $\delta^{15} \mathrm{~N}$ corresponds to the 2 size groups: small haddock ( $\leq 20 \mathrm{~cm}$ in length) and larger haddock $(>20 \mathrm{~cm})$. The TL of the smallest group is below 3.0, which indicates that they feed at least partly on prey that have lower $\delta^{15} \mathrm{~N}$ values than does Calanus finmarchicus. As we assume small haddock do not feed on phytoplankton, the likely prey items for the YOY haddock are euphausiids, amphipods and copepods. Some amphipods have very low $\delta^{15} \mathrm{~N}$, for example the genus Gammarus in the adjacent Sørfjord (Nilsen et al. 2008) and amphipods from kelp forests (Fredriksen 2003). This could partly explain the low $\delta^{15} \mathrm{~N}$ in YOY haddock. It is no surprise that predatory fish feed at higher trophic levels when they increase in size because as they grow they can feed upon larger prey, and the range of possible prey generally increases with size (Cohen et al. 1993, Jennings et al. 2002). Shifts from planktivory to piscivory have been described for many species (Post 2003, Graham et al. 2007), and haddock in Ullsfjord may shift from feeding on small pelagic zooplankton, euphausiids and amphipods to larger crustaceans such as the abundant shrimp species Pandalus borealis and Pasiphea multidentata, as well as benthic invertebrates and small fish. Further investigations are necessary to precisely determine the prey species of haddock.

The slightly more negative $\delta^{13} \mathrm{C}$ values after correction for lipids (Eq. 1) may contribute to some misinterpretations. The $\delta^{13} \mathrm{C}$ signature of the smallest group of haddock even became more depleted than that of the herbivorous copepod Calanus finmarchicus, and it is difficult to interpret whether this is an effect of the conversion method or if the haddock feed on prey that have more depleted isotope signatures. The smallest group of haddock had, on average, a lower $\mathrm{C}: \mathrm{N}$ ratio compared with the other groups and this led to increased difference between the size groups. However, the trends from the results were the same when non-corrected values were used in the comparisons and therefore the converseion method does not influence the conclusions of the study.

\section{Trophic level calculations}

The baseline for TL calculations, the copepod Calanus finmarchicus, was assumed to be a strict herbivore at TL $=2$ as described in Nilsen et al. (2008). However, $\delta^{15} \mathrm{~N}$ and the TL of $C$. finmarchicus can vary throughout the year (Søreide et al. 2006). Also, from Trondheimsfjorden farther south in Norway, Saage et al. (2008) found that $C$. finmarchicus had an average TL of 2.4 and the highest $\delta^{15} \mathrm{~N}$ in this copepod occurred in February before the spring bloom started. Thus, the assumption that our baseline organism, C. finmarchicus, is found strictly at TL 2.0 may be questionable. If a TL of 2.4 was used, the TL of all fish would increase by $0.4 \mathrm{TL}$, giving the smallest group of haddock a TL of 3.05 and whiting a TL of 3.74. For the enrichment factor $\left(\Delta \delta^{15} \mathrm{~N}\right)$ we chose to use $3.4 \%$ as this value is a good overall average (Minagawa \& Wada 1984, Post 2002). However, Sweeting et al. (2007) suggested using 3.2\% for investigations where fish muscle was sampled, as in this study, while Hobson \& Welch (1992) suggested $3.8 \%$ as an overall average fractionation factor. Changing the $\Delta \delta^{15} \mathrm{~N}$ to $3.2 \%$ or $3.8 \%$ would give the same trend; the smallest group of haddock would still be below a TL of 3.0.

\section{Comparison with other demersal fish species}

The abrupt change in both carbon and nitrogen isotopes with increasing length was not displayed by cod, which suggests that the small haddock occupy a different niche from both large haddock and small and large cod (Figs. 4 \& 5). It is important to note that all samples were collected from bottom trawls at depths of 125 to $425 \mathrm{~m}$, and it is likely that some small cod use the sublittoral zone as a nursery area (Berg \& Pedersen 2001). For large cod and haddock the stable isotope signatures overlapped almost completely (Figs. $5 \& 7$ ). Though the maximum length of cod $(106 \mathrm{~cm})$ was larger than that of the haddock $(75 \mathrm{~cm})$, they did not seem to feed at a higher TL as indicated by their $\delta^{15} \mathrm{~N}$ values (Fig. 5). This was surprising as 
large cod have been reported to be more piscivorous opportunistic feeders than haddock (Palsson 1994, Høines \& Bergstad 1999). In the adjacent fjord to Ullsfjord, Sørfjord, cod was the dominant predator (Pedersen et al. 2008) and had the highest $\delta^{15} \mathrm{~N}$ of the predatory fish species (Nilsen et al. 2008). Pálsson (1994) reported that fish constituted, on average, over $50 \%$ of the diet in the North Atlantic cod stocks. In support of this, Dalpadado \& Bogstad (2004) investigated cod in the Barents Sea and found that by the age of $2 \mathrm{yr}$, fish constituted an average $50 \%$ of their diet. However, there is also evidence that both haddock and cod can be opportunistic feeders when there are high abundances of other prey. From Ullsfjord, euphausiids and the shrimp Pandalus borealis were important prey for cod throughout the year (dos Santos \& Falk-Petersen 1989). Høines \& Bergstad (1999) concluded that haddock was primarily benthivorous, but when herring Clupea harengus eggs were abundant both cod and haddock fed on these. Bogetveit et al. (2008) found that when capelin Mallotus villosus was abundant in the Barents Sea, haddock and cod both fed on the high availability of this nutritious food source even if it was only for a short period of time. Our results suggest that large individuals of both species are opportunistic feeders and feed on the same abundant food sources in Ullsfjord. The results show how one species can have very different feeding habits within a limited size range and between geographic areas. The results can be useful when planning food web models as a wide range of fish sizes are not always sampled.

The demersal fish species sampled are the main species in the fjord system with regard to biomass. It was interesting to observe that when we excluded the cod over $45 \mathrm{~cm}$ in length, cod had the lowest $\delta^{15} \mathrm{~N}$ of the demersal species in the size range 25 to $45 \mathrm{~cm}$. The cod may be using a larger range of feeding niches and feed on, for example, the benthic spider crab Hyas sp. (Kanapathippillai et al. 1994) as well as the amphipod Gammarus sp. as both species have very low nitrogen signatures (Nilsen et al. 2008). Preliminary diet investigations from Ullsfjord show that cod feed on a variety of crustaceans (data not shown).

The isotope signatures of haddock overlapped closely with those of whiting and long rough dab and partly with those of witch flounder, which means that they prey on similar species in Ullsfjord (Figs. 6 \& 7) Many trophic pathways can lead to similar isotope signatures in top predators; it is possible that the resources are split up, but preliminary diet investigations show that euphausiids and shrimp are important prey for many of these species (data not shown).
The stable isotope signature can be used as a quantitative measure of a species' niche because it represents a time-integrated average of all prey species. That many species occupy a similar niche at the same trophic level is a strong indication of trophic redundancy, i.e. a large proportion of species is characterized by similar trophic ecologies (Layman et al. 2007). The euphausiids Meganyctiphanes norvegica and Thysanoessa raschii are very abundant in Ullsfjord (Zhou et al. 2005) as are the shrimp species Pandalus borealis and Pasiphea multidentata (data not shown). Therefore, interspecific competition is not necessarily high even if the demersal fish species feed on the same food source.

\section{Haddock in other areas}

Haddock is generally assumed to be a benthic feeder (Wainright et al. 1993, Høines \& Bergstad 1999, Mente et al. 2008). Diet investigations have shown that haddock feed mostly on benthic invertebrates such as polychaetes, brittle stars (ophiurids) and crustaceans (e.g. Mattson 1992, Albert 1995, Dame \& Christian 2008). From the North Sea, haddock feed almost exclusively on benthos and infauna (Schuckel et al. 2010) or nocturnally on sandeel Ammodytes marinus, when the burying species in practice becomes a benthic prey (Temming et al. 2004). From the Barents Sea, Jiang \& Jørgensen (1996) found that small haddock fed more on crustaceans and annelids but less on echinoderms and fish compared with haddock $>20 \mathrm{~cm}$. This is partly in agreement with our results as it showed that haddock changed their diet at the same size as found in our investigations. However, haddock in Iceland prey on deep-water shrimp Pandalus borealis and euphausiids when these are abundant (Bjørnsson et al. 2011). The demersally associated diet of haddock is also reflected in the few published isotopic investigations (Table 2). From Icelandic commercial catches, Sarà et al. (2009) found haddock $\delta^{13} \mathrm{C}$ to be $-16.6 \%$, and from Georges Bank, Fry (1988) found haddock $\delta^{13} \mathrm{C}$ to be $-16.3 \%$. Both these values were clearly enriched compared with the particulate organic material (POM) from the same investigations (-21.1\%o and $-21.3 \%$, respectively). POM can be used as a measure of the pelagic carbon, meaning that the haddock in these investigations probably fed on fauna associated with the benthos.

In Sørfjord, the fjord upstream of Ullsfjord, Nilsen et al. (2008) published $\delta^{13} \mathrm{C}$ values uncorrected for lipid content, and after lipid correction by Eq. (1) 
Table 2. Gadus morhua and Melanogrammus aeglefinus. Stable isotope signatures of cod and haddock as found in the literature. Mean $\delta^{13} \mathrm{C}$ and $\delta^{15} \mathrm{~N}, \mathrm{n}$ and length range given in the literature where both cod and haddock were investigated. na: not available

\begin{tabular}{|c|c|c|c|c|c|c|c|c|c|}
\hline \multirow[t]{2}{*}{ Area } & \multicolumn{4}{|c|}{ Cod } & \multirow[b]{2}{*}{$\delta^{13} \mathrm{C}$} & \multicolumn{2}{|c|}{ — Haddock } & \multirow{2}{*}{$\begin{array}{c}\overline{\text { Length }} \\
\text { range }(\mathrm{cm})\end{array}$} & \multirow{2}{*}{ Reference } \\
\hline & $\delta^{13} \mathrm{C}$ & $\delta^{15} \mathrm{~N}$ & $\mathrm{n}$ & $\begin{array}{l}\text { Length } \\
\text { range }(\mathrm{cm})\end{array}$ & & $\delta^{15} \mathrm{~N}$ & $\mathrm{n}$ & & \\
\hline Ullsfjord & $-19.6^{a}$ & 13.7 & 58 & $10-115$ & $-20.1^{a}$ & 13.0 & 75 & $16-75$ & Present study \\
\hline Sørfjord & $\begin{array}{l}-18.3^{\mathrm{a}} \\
-18.6^{\mathrm{a}}\end{array}$ & $\begin{array}{l}15.3 \\
14.3\end{array}$ & $\begin{array}{r}10 \\
4\end{array}$ & $\begin{array}{l}>35 \\
<35\end{array}$ & $-17.9^{a}$ & 14.8 & 4 & $50-53^{c}$ & Nilsen et al. (2008) \\
\hline Iceland & -17.0 & 12.8 & 6 & na & -16.6 & 13.6 & 4 & na & Sarà et al. (2009) \\
\hline North Sea (southern) & $-16.3^{b}$ & 19.2 & 6 & $37-95$ & $-16.9^{b}$ & 14.8 & 1 & 40 & Das et al. (2003) \\
\hline West Greenland & $\begin{array}{l}-18.1^{b} \\
-18.1^{b} \\
-17.3^{b}\end{array}$ & $\begin{array}{l}13.1 \\
13.1 \\
15.5\end{array}$ & $\begin{array}{r}13 \\
25 \\
4\end{array}$ & $\begin{array}{l}26-46 \\
51-64 \\
66-70\end{array}$ & $-18.0^{b}$ & 13.0 & 12 & $18-24$ & Møller (2006) \\
\hline Gulf of St. Lawrence & $\begin{array}{l}-19.5^{b} \\
-19.2^{b}\end{array}$ & $\begin{array}{l}14.6 \\
15.8\end{array}$ & $\begin{array}{r}11 \\
9\end{array}$ & $\begin{array}{l}14.5-32 \\
33-44.6\end{array}$ & $-19.6^{b}$ & 14.7 & 1 & 18.5 & Lesage et al. (2001) \\
\hline Georges Bank & -16.4 & 12.6 & 1 & na & -16.3 & 12.2 & 2 & na & Fry (1988) \\
\hline $\begin{array}{l}{ }^{\mathrm{a}} \text { Values were lipid-co } \\
\text { bSamples were chemi } \\
{ }^{\mathrm{b}} \text { Values from personal }\end{array}$ & $\begin{array}{l}\text { rected } \\
\text { cally tre } \\
\text { commu }\end{array}$ & $\begin{array}{l}\text { ing Eq } \\
\text { ted to I } \\
\text { ication }\end{array}$ & $\begin{array}{l}\text { (1) } \\
\text { mov } \\
\text { with }\end{array}$ & $\begin{array}{l}\text { e lipids } \\
\text { author }\end{array}$ & & & & & \\
\hline
\end{tabular}

using the C:N ratios supplied ( $\mathrm{M}$. Nilsen pers. comm.), $\delta^{13} \mathrm{C}$ for the 3 haddock $\geq 50 \mathrm{~cm}$ and for the copepod Calanus finmarchicus became $-17.9 \%$ and $-18.2 \%$, respectively. C. finmarchicus in Ullsfjord had a mean lipid-corrected $\delta^{13} \mathrm{C}$ of $-19.9 \%$, and the $1.7 \%$ higher value in the relative shallow Sørfjord may be due to the contribution to the detritus from kelp and macroalgae that have higher $\delta^{13} \mathrm{C}$ values than do phytoplankton (Fredriksen 2003). The largest group of haddock in Ullsfjord $(>50 \mathrm{~cm})$ had a lipid-corrected value for $\delta^{13} \mathrm{C}$ of $-19.4 \%$ and the $1.5 \%$ higher value for haddock in Sørfjord is similar to the difference between the fjords for the baseline organism C. finmarchicus. This indicates that haddock have similar feeding patterns in the 2 fjords.

Most studies of stable isotopes on haddock give one general mean and SD value and do not investigate length groups (Table 2). Sample sizes are also in many cases very small and length range is not included in some papers. Furthermore, haddock under $20 \mathrm{~cm}$ are rarely included. The food web in waters of West Greenland was investigated by Møller (2006) and he sampled stable isotopes of haddock in the length group 18 to $24 \mathrm{~cm}$ total length and found the $\delta^{13} \mathrm{C}$ of haddock there to be $-18.0 \%$ ( SD, 0.3 ), which suggests a higher proportion of pelagic feeding than has been described in previous literature. One haddock of $18.5 \mathrm{~cm}$ was included in the survey in the Gulf of St. Lawrence, Canada, by Lesage et al. (2001) and this haddock had a $\delta^{13} \mathrm{C}$ of
$-19.6 \%$, a value that was depleted and matched the pelagic shrimp Pasiphea multidentata from the same investigation. This may indicate that young haddock in some areas are eating pelagic food, similar to the pattern found in Ullsfjord. Mattson (1992) pointed out that haddock are poorly adapted to eat pelagic food because their mouth is situated sub-terminally. He also claimed that haddock would only eat pelagic food if it happened to be close to the bottom. This does not correspond with our analysis, which suggests that haddock at a young stage feed higher in the water column relative to larger haddock. We cannot see how the $\delta^{13} \mathrm{C}$ signature could be depleted unless significant parts of their diet came from the pelagic food web over a long period of time. It is possible that because of high predation pressure as well as competition from other large demersal species in the near-bottom habitat, the small haddock have adapted to searching for food higher in the water column and this is an example of intraspecific, sizedependent niche diversification and ontogenetic niche change. This adaption can possibly increase survival of small haddock.

Our investigation in Ullsfjord covered a large range of length groups of cod and haddock. We propose to use stable isotopes to investigate feeding changes and when building food web models as differences in feeding preference and ontogenetic niche changes are essential to understanding food web ecology. 


\section{CONCLUSIONS}

Haddock have an ontogenetic shift in stable isotope signatures that reflect a shift in diet from pelagic to benthic prey shortly after growing to $20 \mathrm{~cm}$ in length. Atlantic cod have a gradual change from a partly pelagic to a more benthic diet as they grow. Small haddock seem to have a diet that is very different from both large haddock and small and large cod. Several large demersal fish species seem to be at a similar trophic level in Ullsfjord as indicated by their $\delta^{15} \mathrm{~N}$ and their $\delta^{13} \mathrm{C}$ signatures, which overlap and thus show a strong indication of trophic redundancy.

Acknowledgements. We thank the crew of RV 'Johan Ruud' (University of Tromsø [UT]) as well as research assistant T. Ivarjord (UT) for help with sampling in the field and technician H. Meissner (UT) for assistance with preparing samples for stable isotope analysis. This work was funded by the Norwegian Research Council (NFR) as part of the project 'Investigating coastal ecosystem structure and dynamics using Ecopath/Ecosim ecosystem models and stable isotope data' (project no.190360) under the program 'The Oceans and Coastal Areas'. The work was conducted at the Department of Arctic and Marine Biology, University of Tromsø, Norway.

\section{LITERATURE CITED}

Abrantes KG, Semmens JM, Lyle JM, Nichols PD (2012) Normalisation models for accounting for fat content in stable isotope measurements in salmonid muscle tissue. Mar Biol 159:57-64

> Albert OT (1995) Diel changes in food and feeding of small gadoids on a coastal bank. ICES J Mar Sci 52:873-885

Berg E, Pedersen T (2001) Variability in recruitment, growth and sexual maturity of coastal cod (Gadus morhua L.) in a fjord system in northern Norway. Fish Res 52:179-189

Bergstad OA, Jorgensen T, Dragesund O (1987) Life-history and ecology of the gadoid resources of the Barents Sea. Fish Res 5:119-161

Björnsson B, Reynisson P, Solmundsson J, Valdimarsson H (2011) Seasonal changes in migratory and predatory activity of two species of gadoid preying on inshore northern shrimp Pandalus borealis. J Fish Biol 78: 1110-1131

Bogetveit FR, Slotte A, Johannessen A (2008) The ability of gadoids to take advantage of a short-term high availability of forage fish: the example of spawning aggregations in Barents Sea capelin. J Fish Biol 72:1427-1449

Bugge J, Barrett RT, Pedersen T (2011) Optimal foraging in chick-raising common guillemots (Uria aalge). J Ornithol 152:253-259

Cabana G, Rasmussen JB (1996) Comparison of aquatic food chains using nitrogen isotopes. Proc Natl Acad Sci USA 93:10844-10847

Cohen JE, Pimm SL, Yodzis P, Saldana J (1993) Body sizes of animal predators and animal prey in food webs. J Anim Ecol 62:67-78

> Dalpadado P, Bogstad B (2004) Diet of juvenile cod (age 0-2) in the Barents Sea in relation to food availability and cod growth. Polar Biol 27:140-154
Dalpadado P, Bogstad B, Eriksen E, Rey L (2009) Distribution and diet of 0-group cod (Gadus morhua) and haddock (Melanogrammus aeglefinus) in the Barents Sea in relation to food availability and temperature. Polar Biol 32: 1583-1596

Dame JK, Christian RR (2008) Evaluation of ecological network analysis: validation of output. Ecol Model 210: 327-338

> Das K, Lepoint G, Leroy Y, Bouquegneau JM (2003) Marine mammals from the southern North Sea: feeding ecology data from $\delta^{13} \mathrm{C}$ and $\delta^{15} \mathrm{~N}$ measurements. Mar Ecol Prog Ser 263:287-298

Demain DK, Gallego A, Jaworski A, Priede IG, Jones EG (2011) Diet and feeding niches of juvenile Gadus morhua, Melanogrammus aeglefinus and Merlangius merlangus during the settlement transition in the northern North Sea. J Fish Biol 79:89-111

$>$ dos Santos J, Falk-Petersen S (1989) Feeding ecology of cod (Gadus morhua L.) in Balsfjord and Ullsfjord, northern Norway, 1982-1983. ICES J Mar Sci 45:190-199

Frank KT, Petrie B, Shackell NL (2007) The ups and downs of trophic control in continental shelf ecosystems. Trends Ecol Evol 22:236-242

Fredriksen S (2003) Food web studies in a Norwegian kelp forest based on stable isotope $\left(\delta^{13} \mathrm{C}\right.$ and $\left.\delta^{15} \mathrm{~N}\right)$ analysis. Mar Ecol Prog Ser 260:71-81

> Fry B (1988) Food web structure on Georges Bank from stable $\mathrm{C}, \mathrm{N}$, and $\mathrm{S}$ isotopic compositions. Limnol Oceanogr 33:1182-1190

Godø OR, Gjøsæter J, Sunnanå K, Dragesund O (1989) Spatial distribution of 0-group gadoids off mid-Norway. Rapp P-V Réun Cons Int Explor Mer 191:273-280

> Graham BS, Grubbs D, Holland K, Popp BN (2007) A rapid ontogenetic shift in the diet of juvenile yellowfin tuna from Hawaii. Mar Biol 150:647-658

> Hobson KA, Welch HE (1992) Determination of trophic relationships within a high Arctic marine food web using $\delta^{13} \mathrm{C}$ and $\delta^{15} \mathrm{~N}$ analysis. Mar Ecol Prog Ser 84:9-18

Hobson KA, Fisk A, Karnovsky N, Holst M, Gagnon JM, Fortier $M(2002)$ A stable isotope $\left(\delta^{13} \mathrm{C}, \delta^{15} \mathrm{~N}\right)$ model for the North Water food web: implications for evaluating trophodynamics and the flow of energy and contaminants. Deep-Sea Res II 49:5131-5150

Høines AS, Bergstad OA (1999) Resource sharing among cod, haddock, saithe and pollack on a herring spawning ground. J Fish Biol 55:1233-1257

ICES (International Council for the Exploration of the Sea) (2011) Book 3. The Barents Sea and the Norwegian Sea. In: Report of the ICES Advisory Committee, 2011. ICES Advice, Copenhagen

> Jennings S, Greenstreet SPR, Hill L, Piet GJ, Pinnegar JK, Warr KJ (2002) Long-term trends in the trophic structure of the North Sea fish community: evidence from stableisotope analysis, size-spectra and community metrics. Mar Biol 141:1085-1097

> Jiang W, Jørgensen T (1996) The diet of haddock (Melanogrammus aeglefinus L) in the Barents Sea during the period 1984-1991. ICES J Mar Sci 53:11-21

Kanapathippillai P, Berg E, Dossantos J, Gulliksen B, Pedersen T (1994) The food consumption of cod Gadus morhua L. in a high-latitude enhancement area. Aquacult Fish Manag 25(Suppl1):65-76

Layman CA, Arrington DA, Montana CG, Post DM (2007) Can stable isotope ratios provide for community-wide measures of trophic structure? Ecology 88:42-48 
Lesage V, Hammill MO, Kovacs KM (2001) Marine mammals and the community structure of the Estuary and Gulf of St Lawrence, Canada: evidence from stable isotope analysis. Mar Ecol Prog Ser 210:203-221

Mattson S (1992) Food and feeding habits of fish species over a soft sublittoral bottom in the Northeast Atlantic3. Haddock (Melanogrammus aeglefinus (L)) (Gadidae). Sarsia 77:33-45

Mente E, Pierce GJ, Spencer NJ, Martin JC and others (2008) Diet of demersal fish species in relation to aquaculture development in Scottish sea lochs. Aquaculture 277:263-274

Minagawa M, Wada E (1984) Stepwise enrichment of ${ }^{15} \mathrm{~N}$ along food chains: further evidence and the relation between $\delta^{15} \mathrm{~N}$ and animal age. Geochim Cosmochim Acta 48:1135-1140

Møller P (2006) Lipids and stable isotopes in marine food webs in West Greenland. Trophic relations and health implications. PhD thesis, Technical University of Denmark, Lyngby

Newsome SD, del Rio CM, Bearhop S, Phillips DL (2007) A niche for isotopic ecology. Front Ecol Environ 5:429-436

> Nilsen M, Pedersen T, Nilssen EM, Fredriksen S (2008) Trophic studies in a high-latitude fjord ecosystem-a comparison of stable isotope analyses $\left(\delta^{13} \mathrm{C}\right.$ and $\left.\delta^{15} \mathrm{~N}\right)$ and trophic-level estimates from a mass-balance model. Can J Fish Aquat Sci 65:2791-2806

> Nøstvik F, Pedersen T (1999) Catching cod for tagging experiments. Fish Res 42:57-66

Pálsson OK (1994) A review of the trophic interactions of cod stocks in the North Atlantic. In: Jakobsson J, Atthorsson OS, Beverton RJH, Bjornsson B and others (eds) Cod and climate change-proceedings of a symposium. Book 198. ICES, Copenhagen

> Pedersen T, Fossheim M (2008) Diet of 0-group stages of capelin Mallotus villosus, herring Clupea harengus and cod Gadus morhua during spring and summer in the Barents Sea. Mar Biol 153:1037-1046

Pedersen T, Nilsen M, Nilssen EM, Berg E, Reigstad M (2008) Trophic model of a lightly exploited cod-dominated ecosystem. Ecol Model 214:95-111

Peterson BJ, Fry B (1987) Stable isotopes in ecosystem studies. Annu Rev Ecol Syst 18:293-320

Petursdottir H, Gislason A, Falk-Petersen S, Hop H, Svavarsson J (2008) Trophic interactions of the pelagic ecosystem over the Reykjanes Ridge as evaluated by fatty acid and stable isotope analyses. Deep-Sea Res II 55:83-93

Post DM (2002) Using stable isotopes to estimate trophic position: models, methods, and assumptions. Ecology 83: 703-718

> Post DM (2003) Individual variation in the timing of ontogenetic niche shifts in largemouth bass. Ecology 84: 1298-1310

Post DM, Layman CA, Arrington DA, Takimoto G, Quattrochi J, Montana CG (2007) Getting to the fat of the

Editorial responsibility: Antonio Bode,

A Coruña, Spain matter: models, methods and assumptions for dealing with lipids in stable isotope analyses. Oecologia 152: 179-189

> Robb AP, Hislop JRG (1980) The food of five gadoid species during the pelagic 0-group phase in the Northern North Sea. J Fish Biol 16:199-217

> Saage A, Altin D, Vadstein O, Sommer U (2008) Trophic position of Calanus finmarchicus (Copepoda, Calanoida) in the Trondheim Fjord. J Sea Res 59:162-172

> Sarà G, De Pirro M, Sprovieri M, Rumolo P, Halldorsson HP, Svavarsson J (2009) Carbon and nitrogen stable isotopic inventory of the most abundant demersal fish captured by benthic gears in southwestern Iceland (North Atlantic). Helgol Mar Res 63:309-315

Schückel S, Ehrich S, Kroncke I, Reiss H (2010) Linking prey composition of haddock Melanogrammus aeglefinus to benthic prey availability in three different areas of the northern North Sea. J Fish Biol 77:98-118

Shaw M, Diekmann R, van der Kooij J, Milligan S, Bromley P, Righton D (2008) Assessment of the diets of cod Gadus morhua and whiting Merlangius merlangus juveniles in a frontal region close to the Norwegian Trench: coexistence or competition? J Fish Biol 73:1612-1634

Søreide JE, Hop H, Carroll ML, Falk-Petersen S, Hegseth EN (2006) Seasonal food web structures and sympagicpelagic coupling in the European Arctic revealed by stable isotopes and a two-source food web model. Prog Oceanogr 71:59-87

Svanbäck R, Bolnick DI (2007) Intraspecific competition drives increased resource use diversity within a natural population. Proc R Soc Lond B Biol Sci 274:839-844

Sweeting CJ, Barry J, Barnes C, Polunin NVC, Jennings S (2007) Effects of body size and environment on diet-tissue $\delta^{15} \mathrm{~N}$ fractionation in fishes. J Exp Mar Biol Ecol 340:1-10

Temming A, Götz S, Mergardt N, Ehrich S (2004) Predation of whiting and haddock on sandeel: aggregative response, competition and diel periodicity. J Fish Biol 64: 1351-1372

Wainright SC, Fogarty MJ, Greenfield RC, Fry B (1993) Long-term changes in the Georges Bank food web: trends in stable isotopic composition of fish scales. Mar Biol 115:481-493

- Weidel BC, Carpenter SR, Kitchell JF, Vander Zanden MJ (2011) Rates and components of carbon turnover in fish muscle: insights from bioenergetics models and a wholelake ${ }^{13} \mathrm{C}$ addition. Can J Fish Aquat Sci 68:387-399

> Wells RJD, Cowan JH Jr, Fry B (2008) Feeding ecology of red snapper Lutjanus campechanus in the northern Gulf of Mexico. Mar Ecol Prog Ser 361:213-225

> Werner EE, Gilliam JF (1984) The ontogenetic niche and species interactions in size structured populations. Annu Rev Ecol Syst 15:393-425

> Zhou M, Zhu YW, Tande KS (2005) Circulation and behavior of euphausiids in two Norwegian sub-Arctic fjords. Mar Ecol Prog Ser 300:159-178

Submitted: September 14, 2011; Accepted: January 13, 2012 Proofs received from author(s): April 2, 2012 